\title{
ANALYSIS AND ASSESSMENT OF HEAVY METALS CONCENTRATIONS IN NEMUNAS RIVER BOTTOM SEDIMENTS AT ALYTUS CITY TERRITORY
}

\author{
Vaidotas VALSKYS, Roberta VALSKIENĖ, Gytautas IGNATAVIČIUS \\ Ecology and Environmental Center, Vilnius University, Vilnius, Lithuania
}

Submitted 06 March 2014; accepted 26 Aug. 2014

\begin{abstract}
Concentrations and spatial distribution of heavy metals on the left and right banks of the river Nemunas bottom sediments are analyzed in this article. The research methodology of X-ray fluorescence spectrometry for bottom sediments and operating principles of XL2 spectrometer used for analysis are overviewed. The results of analysis are presented and compared with LAND 20-2005 requirements as well as studies that were carried out previously. The influence of Alytus city for Nemunas river sediments quality is assessed. Dischargers formed additional samples which were taken and included to the list of ordinary samples. The trend of heavy metals $(\mathrm{Cd}$, $\mathrm{Cu}, \mathrm{Cr}$ ) concentrations showed the growth of pollution downstream the urban area. The estimated $\mathrm{Zd}$ (total pollution) values clearly indicated higher contamination by heavy metals on the left bank of Nemunas River. Extensive surveys of river sediments allow assessing the extent of anthropogenic impact, which can be harmful to the river ecosystem and human health.
\end{abstract}

Keywords: $\mathrm{x}$-ray fluorescence spectrometry, heavy metals, sediments, water pollution.

\section{Introduction}

The present day river bottom sediments are complex mechanical, mineral and chemical composition heterogeneous polydispersed system which is sensitive to the change of surrounding environment physical and chemical conditions. Typically river sediments are formed from the mineral part of the river banks surrounding landscape, various chemical and mechanical maturity subsoil and rock soil constituents (Jankauskaite et al. 2008). In addition, dead and unevenly decomposed biomass, manganese, iron and other elements hydroxides participates in sediments formation. In recent decades, the particularly important factors that determined sediments macro- and microelement composition has become of human productive and economic activity (Chalmers et al. 2006).

Heavy metals (HM) transport, access to river and accumulation in sediments are determined by natural and anthropogenic factors as a result of the self-purification of river water (Taraškevičius, Zinkute 2011). HM which have low solubility and biodegradation characteristics are more accumulated in sediments. Usually in unaffected environments, the concentration of most of the metals in rivers is very low and is mostly derived from weathering of rock and soil (Reza, Singh 2010). In addition to natural factors concentrations of heavy metals in river sediments depend on the type of anthropogenic effect, intensity and duration. Urban environment is a complicated system, because $70-90 \%$ of all the soil lies under the streets, pedestrian paths, buildings and therefore, its natural environmental recovery takes a lot of time, a natural energy and material circulation are destroyed (Vasarevičius et al. 2010). The highest accumulation of metals occurs in low flow period and the lowest accumulation of metals occurs during the high flow period, suggesting that the concentration of heavy metals in bed sediments is brought about by changes of water flow (Bartoli et al. 2011; Li et al. 2012).

Contaminated sediments have negative impact to the bottom and bottom-dwelling organisms. Such environment leads to the loss or extinction of molluscs, fish and other hydrobionts (Farkas et al. 2007; Lourino-Cabana et al. 2011). In addition, the sediments that are heavily contaminated with toxic substances cause not only diseases or extinct of aquatic wildlife but are also dangerous to animals and humans that are consuming fish. Even if trace metals are initially emitted in their elemental forms, usually considered as non-bioavailable, their ultimate fate

Corresponding author: Vaidotas Valskys

E-mail: vaidas.valskys@gmail.com 
remains unknown. Therefore, urban runoffs not only degrade the environmental quality of aquatic ecosystems, but also lead to increasing contaminants in aquatic organisms through bioaccumulation and biomagnification, potentially causing elevated trace metal concentration in the food chain (Yujun et al. 2011; Sen, Varol 2011). Thus, the primary purposes of sediment quality guidelines are to protect the aquatic biota from the deleterious effects associated with sediment-bound contaminants, to rank and/or prioritize contaminated areas or chemicals of concern for further investigation (Honglei et al. 2007; Fu et al. 2014).

The analysis of HM concentrations and determination of allowable exceedance limits oblige to take measures to improve the quality of human life and the environment. Environmental pollution by HM is a global problem. This phenomenon is very important for river ecosystems which accumulate HM that get from natural and anthropogenic sources (Peng et al. 2008). It has long been accepted that $\mathrm{HM}$ are very important at ecotoxicological point of view as these elements are very persistent and can be toxic. In order to assess the ecological status of surface sediment $s$ and their effects on the biota and human health it is important to measure the concentrations of HM (Davutluoglu et al. 2011).

Mainly due to the lack of methodology and equipment analyses of heavy metals basically have not been carried out until 1990 in Lithuania. First environmental monitoring system was developed in 1991-1992 in Lithuania. Later in 1997 first Lithuanian Environmental Monitoring Program which provided research of $\mathrm{HM}(\mathrm{Zn}, \mathrm{Cu}$,

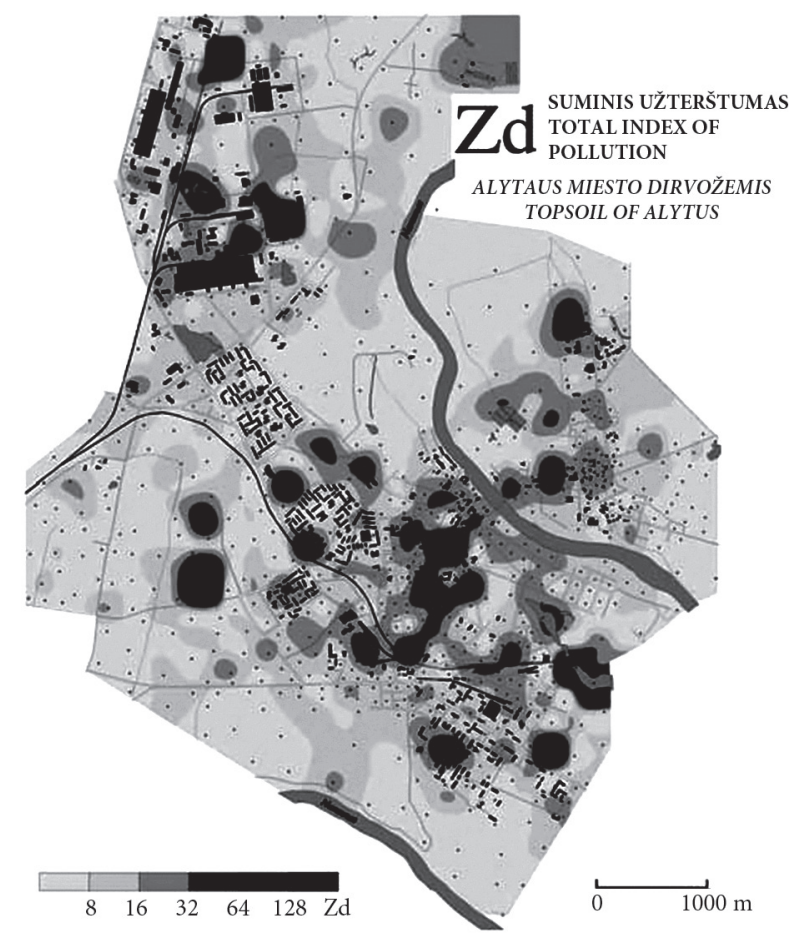

Fig. 1. Soil contamination with heavy metals in Alytus town according to the index Zd (Gregorauskiene 2006)
$\mathrm{Cr}, \mathrm{Pb}, \mathrm{Ni}, \mathrm{Hg}, \mathrm{Cd}$ ) in surface water and sediments has been prepared and approved. Despite the investigations carried out there is still not enough information about the distribution of HM in Lithuanian river sediments (Lithuanian Environmental Protection Agency 2003).

The objective of this work was to investigate and assess the contamination by heavy metals of Nemunas river bottom sediments at Alytus city territory using X-ray fluorescence spectrometry. This territory was chosen due to the lack of this type of research in this area. Also industries are well-developed in this city thus it can lead to an increased concentrations of heavy metals. Such detailed research which is important in determining the pollution sources shows the real distribution of heavy metals concentrations.

Results of researches that were carried out in Alytus city territory clearly shows industry and arbitrary household waste areas that are contaminated with zinc, copper, silver and other elements. Anomalies of heavy metals concentrations were determined near "Snaige" refrigerator factory, textile factory, railway, agricultural machinery factory, garages, lake "Dailide" and other territories (Fig. 1). All industrial and other polluting objects are located in the western part (left bank of the river Nemunas) of the city (Gregorauskienè 2006).

\section{Methodology}

\subsection{General description of the study area}

Sampling locations are set out on the left and right banks of the Nemunas River. $4.5 \mathrm{~km}$ sampling length was selected and it is actually bounded by two bridges in the area. Sampling started above Alytus city from the ruins of the railway bridge (destroyed during the World War I). The end of sampling was below Alytus city near the new bridge of the city ("Lithuania Millennium Bridge").

$4.5 \mathrm{~km}$ sampling length was divided into equal parts at $300 \mathrm{~m}$ (Fig. 2, grey round points). Coordinates of sampling points were set with Garmin GPS Navigator "Nuvi 40". Dischargers and tributaries formed additional samples which were taken and included to the list of ordinary samples (Fig. 2, white square points).

\subsection{Sampling and preparation}

Samples were taken from the surface $(0-0.1 \mathrm{~m})$ sediment layer $1 \mathrm{~m}$ away from the shore. Samples were taken using stainless steel unpainted 7 liter bucket. Sample collection was held in summer which is low runoff period (summer period: $15-18 \%$ of total runoff). Samples were taken $1 \mathrm{~m}$ away from the shore thus granulometric composition of samples were sand and sandy loam (85-95\% of physical sand). Samples were placed in separate polyethylene containers to avoid the cross-contamination. Containers were 
registered indicating the river side and the sample sequence number. Sediment samples were taken to the laboratory and placed in petri dishes. Samples were dried to constant weight in drying oven at $(105 \pm 10)^{\circ} \mathrm{C}$ temperature. Dried samples were grinded in porcelain mortar until homogenous mass. The obtained mass of the sample was filtered through $2.00 \mathrm{~mm}, 250 \mu \mathrm{m}$ and $125 \mu \mathrm{m}$ mesh filter. Filtrated mass were placed in special caps which were inserted into spectrometer (Shu-hai et al. 2006; Suthar et al. 2009). Samples were tested in Thermo Scientific Niton ${ }^{\circledR}$ XL2 series X-ray fluorescence spectrometer.

Measurement time varies from 30 to 600 seconds depending on the intended quality of the results. The optimal 240-second analysis time was chosen to analyze bottom sediments of the Nemunas River (US EPA 2006).

28 elements were analyzed in bottom sediments (As, $\mathrm{Hg}, \mathrm{Cd}, \mathrm{Ba}, \mathrm{Sb}, \mathrm{Sn}, \mathrm{Ag}, \mathrm{Pd}, \mathrm{Zr}, \mathrm{Sr}, \mathrm{Rb}, \mathrm{Pb}, \mathrm{Se}, \mathrm{Au}, \mathrm{Zn}, \mathrm{W}$, $\mathrm{Cu}, \mathrm{Ni}, \mathrm{Co}, \mathrm{Fe}, \mathrm{Mn}, \mathrm{Cr}, \mathrm{V}, \mathrm{Ti}, \mathrm{Sc}, \mathrm{Ca}, \mathrm{K}, \mathrm{S})$. Further analysis involved those metals that are anthropogenic and potentially dangerous.

\subsection{Research device}

Research was carried out using X-ray fluorescence spectrometer - Niton XL2. Spectroscopy is an analytical technique in which dry river bottom sediment sample is exposed to X-rays. The $\mathrm{X}$-rays from the source have the appropriate excitation energy that causes elements in the sample to emit characteristic X-rays. A qualitative elemental analysis is possible from the characteristic energy, or wavelength, of the fluorescent X-rays emitted (Fig. 3).

A quantitative elemental analysis is possible by counting the number (intensity) of X-rays at a given wavelength (Wrobel, Czyzycki 2013). The energy of this X-ray radiation is unique for each element (US EPA 2006).

Each sample is analysed with 3 spectra using 4 different energy lines. Device automatically counts each spectra and each energy line values giving counted errors, element concentration values and detection limit. Detection limit with 240 seconds scanning time gives $2-4$ ppm detection limit depending on each element.

\subsection{The reliability of the X-ray fluorescence (XRF) spectrometry results}

The reliability of XRF analysis method depends on sample preparation (drying, grinding, sieving). Unreliable results are recorded when there are no compliance with recommendations for sampling and preparation (Guoren et al. 2013). The most important requirements for the preparation of samples are grinding and sieving. The particle size of $250 \mu \mathrm{m}$ (preferably $125 \mu \mathrm{m}$ ) must be achieved. Continuous dry matter should be 3 to 5 grams in the sample cup.
An experiment was carried out analyzing lead levels in Massachusetts (USA). Fully prepared XRF samples showed excellent correlation with laboratory Atomic Absorption Spectrometry (AAS) for material split after the final grinding, sieving, and homogenization (Fig. 4). A set of 20 fully prepared XRF samples (oven dried, ground to $0.125 \mathrm{~mm}$ ), including 11 bridge site samples, 6 residential lead samples, and 3 NIST SRM soils, gave a linear regression slope of 1.004 and an $\mathrm{R}^{2}$ of 0.995 . For the 17 samples with lead concentrations above $100 \mathrm{ppm}$, the mean recovery of the XRF relative to AAS was 0.952 and the standard deviation of the recovery was 0.068 , for relative standard deviation (RSD) of 7.1 percent.

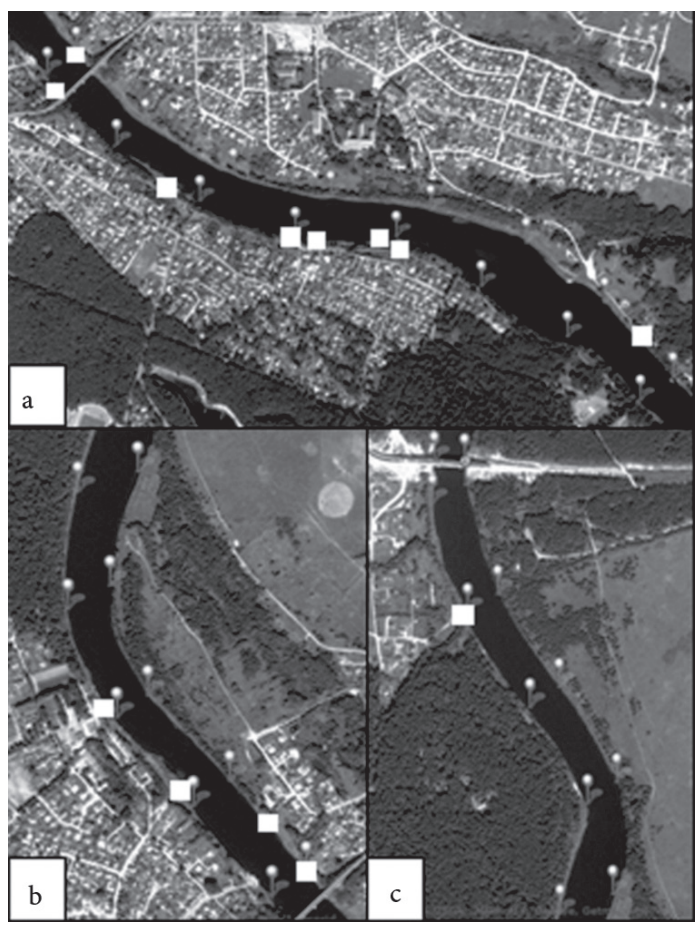

Fig. 2. Sampling locations downstream - Nemunas river above (a), middle (b) and below (c) Alytus city

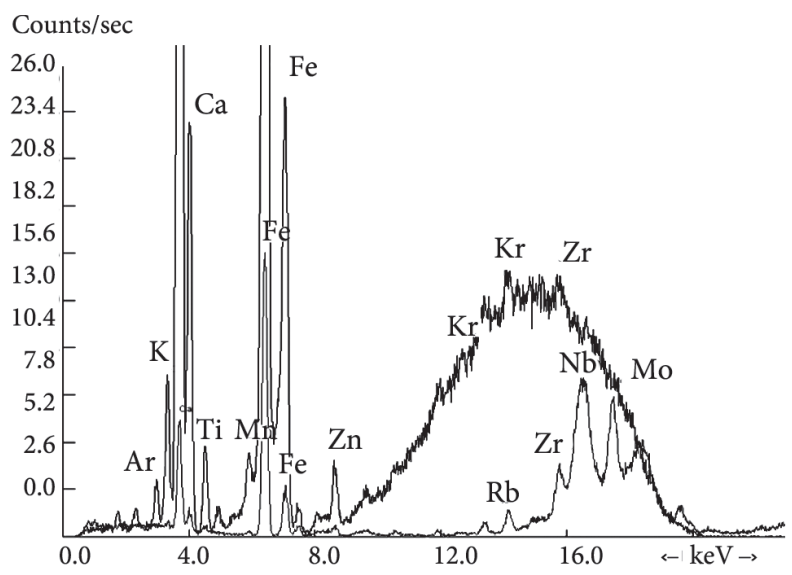

Fig. 3. Niton XL2 window showing wavelength and intensity measurement 


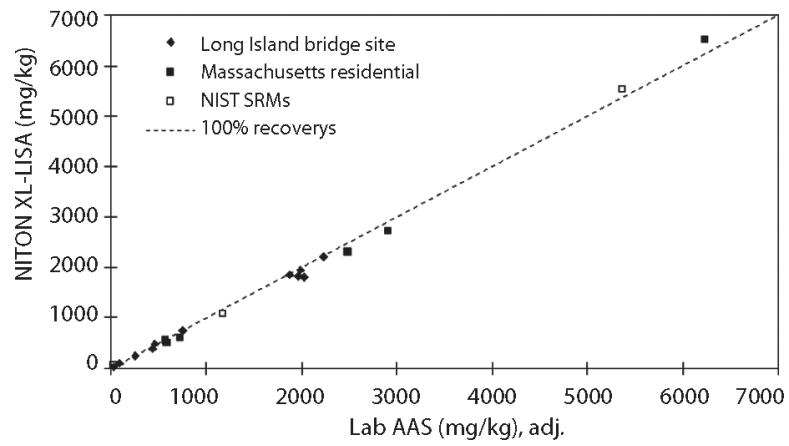

Fig. 4. Comparison of fully prepared XRF and laboratory AAS results

The subset of 11 bridge site samples gave a linear regression slope of 0.958 and correlation coefficient $\left(\mathrm{R}^{2}\right)$ of 0.994. The subset of 6 Massachusetts residential samples gave a linear regression slope of 1.010 and an $\mathrm{R}^{2}$ of 0.994 (Shefsky 1997).

The XRF is much cheaper than the AAS analysis method thus it provides an opportunity to analyze a greater number of samples and obtain a more detailed distribution of HM concentrations in the territory.

\subsection{Total contamination index $(\mathrm{Zd})$}

Zd of HM (Cd, Ni, Cr, Cu, Zn, As, Mn) in bottom sediments was calculated for the left and right bank of the Nemunas River. These HM were chosen due to their potential anthropogenic origin.

Geochemical background values for these elements were taken from Lithuanian Hygiene Standard 60: 2004. There are values given for loam and clay that were chosen as a background values. This decision was made after the comparison of these concentrations with concentrations given in comparative characteristics of change of trace elements background values in Lithuanian surface sediments (Kadūnas, Radzevičius 2003). These values were closest.

Total contamination index is calculated by the formula:

$$
Z_{d}=\sum K_{K}-(n-1)
$$

Values of coefficient of element concentration $\left(K_{K}\right)$ are summed up only if $K_{K}$ values are greater than 1 .

$n$ - number of chemical elements (pollutants);

$K_{K}$ - coefficient of each element concentrations which is calculated for each element separately by the formula:

$$
K_{K}=C / C_{f},
$$

$C$ - determined concentration of chemical element in the sample $(\mathrm{mg} / \mathrm{kg})$;

$\mathrm{C}_{f}$ - background concentration of chemical element in the sample $(\mathrm{mg} / \mathrm{kg})$.

$Z_{d}$ index is used in cases when the subject that is analysed is contaminated by several substances or chemical elements (Lithuanian Hygiene Standard 60: 2004).

\section{Results}

42 samples were analyzed using XRF method and concentrations of heavy metals were determined on the right and left banks of Nemunas River at Alytus city territory.

Nemunas river sediments are not as polluted as some western European countries rivers (Table 1) such as Ireland (Glendasan). This contamination is caused by extraction of metals (mines), heavy industry companies and other polluting objects. There are no such polluting objects in Lithuania thus it leads to the less contaminated soils and river sediments. Heavy metal concentrations in Nemunas river sediments are similar to neighboring countries (Latvia, Poland, etc.).

Table 1. Comparison of HM concentrations in Nemunas river and some rivers in other Europe countries

\begin{tabular}{lcccccc}
\hline \multirow{2}{*}{ River } & \multicolumn{6}{c}{ Heavy metals (mg/kg) } \\
\cline { 2 - 7 } & $\mathrm{Cu}$ & $\mathrm{Pb}$ & $\mathrm{Cr}$ & $\mathrm{Ni}$ & $\mathrm{Cd}$ & $\mathrm{Zn}$ \\
\hline $\begin{array}{l}\text { Glendasan } \\
\text { (Ireland) }\end{array}$ & 291 & 10.22 & - & - & 56 & 17.5 \\
\hline $\begin{array}{l}\text { Mala Welna } \\
\text { (Poland) }\end{array}$ & 13.8 & 13.4 & 3.9 & 8.3 & 0.85 & 43.4 \\
\hline $\begin{array}{l}\text { Bogdanas } \\
\text { (Greece) }\end{array}$ & 44.35 & 10.98 & - & 5.23 & 0.12 & 130.2 \\
\hline $\begin{array}{l}\text { Nemunas } \\
\text { (left bank) }\end{array}$ & 26.88 & - & 60.06 & 61.1 & 14.67 & 27.19 \\
\hline $\begin{array}{l}\text { Nemunas } \\
\text { (right bank) }\end{array}$ & 21.07 & - & 39.42 & - & 13.23 & 21.6 \\
\hline
\end{tabular}

Although concentrations are much lower in Nemunas river than in rivers that are in western Europe countries as industry develops there is a need to investigate the geochemical changes in Lithuania.

Concentrations of 21 metals were determined which were higher than the detection limit. Lithuanian environmental normative document 20-2005 (LAND 20-2005) requirements for sludge categorization by heavy metals were used to compare and evaluate the quality of the sediments.

There is no normative document that regulates concentrations of heavy metals in river bottom sediments in Lithuania. According to the measured concentrations of heavy metals mean values are calculated separately for the left and right banks of the Nemunas River. Those mean values are used to evaluate the general condition of the sludge and compare with the requirements of LAND 20-2005. Most of HM (Cr, Cu, Zn) concentrations in the surface (0-0.1 m deep) layer sediments meets I sludge category.

Higher pollution by heavy metals $(\mathrm{Cd}$ and $\mathrm{Ni}$ ) is observed on the left bank of the Nemunas River. Those metals concentrations correspond to the II sludge category. Only Cd concentration on the right bank of the Nemunas River exceeds the LAND 20-2005 requirements (Table 2). 
Table 2. Sludge categorization by HM concentrations (LAND 20-2005)

\begin{tabular}{|c|c|c|c|c|c|c|c|}
\hline \multirow{2}{*}{ Sludge category } & \multicolumn{7}{|c|}{ Concentrations of heavy metals, $\mathrm{mg} / \mathrm{kg}\left({ }^{*} \mathrm{LOD}\right.$-Level of Detection $)$} \\
\hline & $\mathrm{Pb}$ & $\mathrm{Cd}$ & $\mathrm{Cr}$ & $\mathrm{Cu}$ & $\mathrm{Ni}$ & $\mathrm{Zn}$ & $\mathrm{Hg}$ \\
\hline I & $<140$ & $<1.5$ & $<140$ & $<75$ & $<50$ & & $<1.0$ \\
\hline II & $140-750$ & $1.5-20$ & $140-400$ & $75-1000$ & $50-300$ & $300-2500$ & $1.0-8.0$ \\
\hline III & $>750$ & $>20$ & $>400$ & $>1000$ & $>300$ & $>2500$ & $>8.0$ \\
\hline $\begin{array}{l}\text { Right bank of the } \\
\text { Nemunas River }\end{array}$ & $<\mathrm{LOD}^{\star}$ & 13.23 & 39.42 & 21.07 & $<\mathrm{LOD}^{*}$ & 21.6 & $<\mathrm{LOD}^{*}$ \\
\hline $\begin{array}{l}\text { Left bank of the } \\
\text { Nemunas River }\end{array}$ & $<\mathrm{LOD}^{\star}$ & 14.67 & 60.06 & 26.88 & 61.1 & 27.19 & $<\mathrm{LOD}^{*}$ \\
\hline
\end{tabular}

Such distribution of HM concentrations shows higher contamination load on the left river bank which is possibly caused by industries located in the urban area on the left bank of the river. There are no industrial facilities or other concentrated contamination hotspots on the right river bank.

Cadmium concentrations 8.8 and 9.8 times are greater than required for the I sludge category while nickel concentration exceeds 1.2 times only on the left bank of the Nemunas River. In terms of the worse Indicators River sediments on both banks are assigned to the II sludge category (LAND 20-2005).

Most of the heavy metals concentrations in bottom sediments of the Nemunas River have steadily increased with the exception of $\mathrm{Pb}$ and $\mathrm{Zn}$. $\mathrm{Cr}$ and Ni concentrations are highest in River sediments (Fig. 5). New industrial companies in 2009-2010 were established in the western part of Alytus city instead of old auto repair, motor transport companies. These industrial companies are producing plastic, rubber products and electronics, thus it could have caused the change of heavy metals concentrations. The increase of $\mathrm{Cr}, \mathrm{Ni}$ and $\mathrm{Cd}$ could probably be caused by the change of industrial activity.

Sediments of the Nemunas River were quite polluted in compare with clean (Skroblus) river: it dozens of times exceeded background values with the exception of $\mathrm{Pb}$ which was below the detection limit.

$\mathrm{Cu}$ concentration was similar in Kulpè and Nemunas Rivers bottom sediments (Fig. 6) while Cd concentration was 16 times higher in Kulpe river sediments (Lithuanian Environmental Protection Agency 2003).

\subsection{The trend of HM concentrations in the sediments of the Nemunas River going downstream}

Sample numbers are given on the $\mathrm{x}$ axis in Figures 7-12 (dis. - discharges and trib. - tributaries). The change of heavy metals $(\mathrm{Cr}, \mathrm{Cu}, \mathrm{Cd})$ concentrations on the right and left banks of the Nemunas River was calculated using the trend feature. It is noticeable that $\mathrm{Cd}$ and $\mathrm{Cu}$ concentrations on the left and right banks increase downstream (Figs 7-12). Concentrations of $\mathrm{Cr}$ on the right bank of

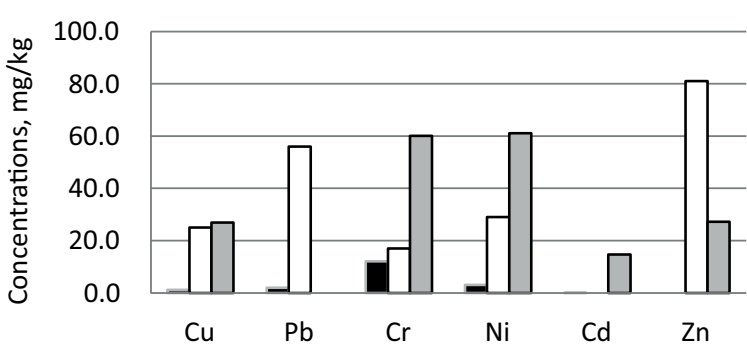

- HM concentrations in 2003 a HM concentrations in 2006

$\square \mathrm{HM}$ concentrations in 2012

Fig. 5. HM concentrations in Nemunas River bottom sediments

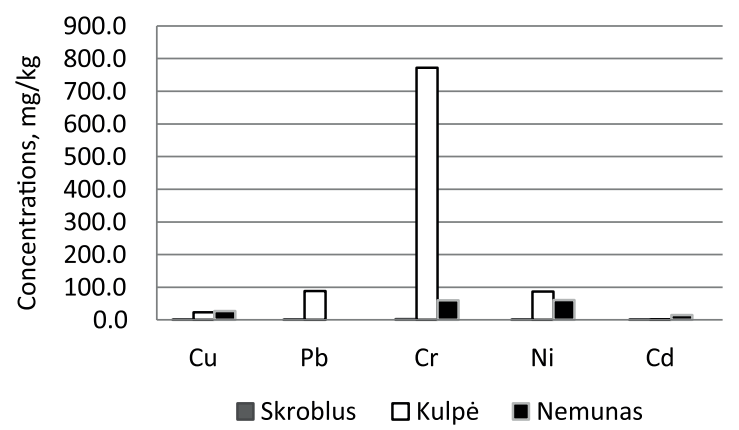

Fig. 6. HM concentrations in bottom sediments of the most contaminated and the cleanest Lithuanian rivers

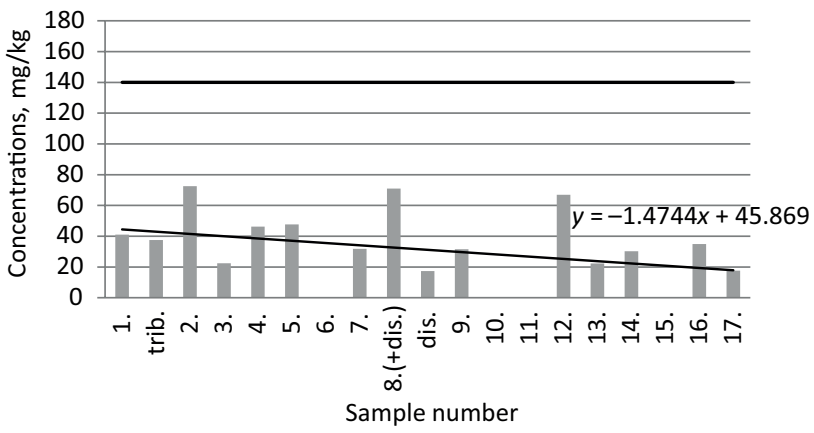

Fig. 7. Cr concentrations on the right bank, downstream trend $(y)$, the concentration of the I sludge category (bold line) 


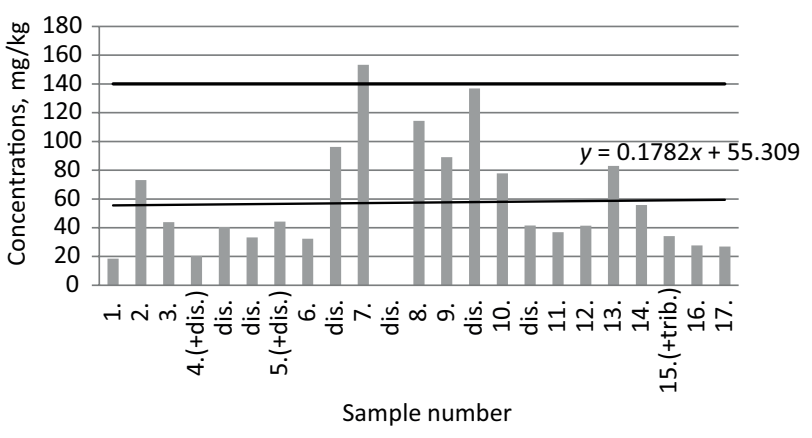

Fig. 8. Cr concentrations on the left bank, downstream trend $(y)$, the concentration of the I sludge category (bold line)

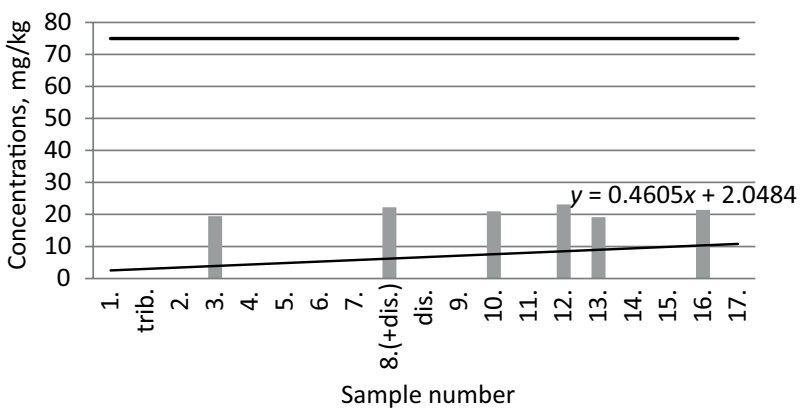

Fig. 9. $\mathrm{Cu}$ concentrations on the right bank, downstream trend $(y)$, the concentration of the I sludge category (bold line)

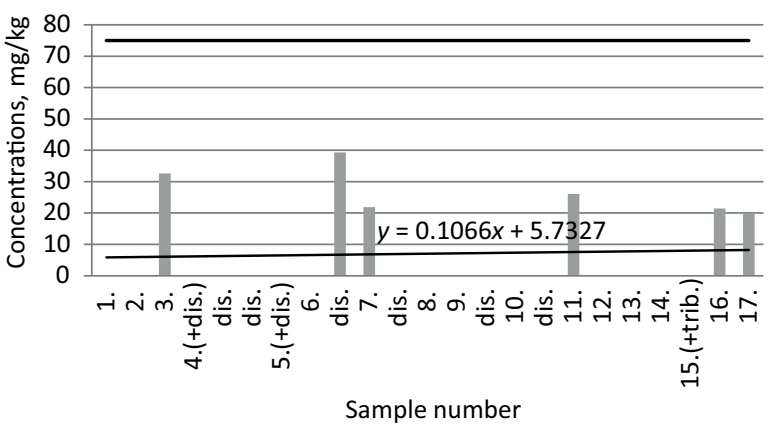

Fig. 10. Cu concentrations on the left bank, downstream trend $(y)$, the concentration of the I sludge category (bold line)

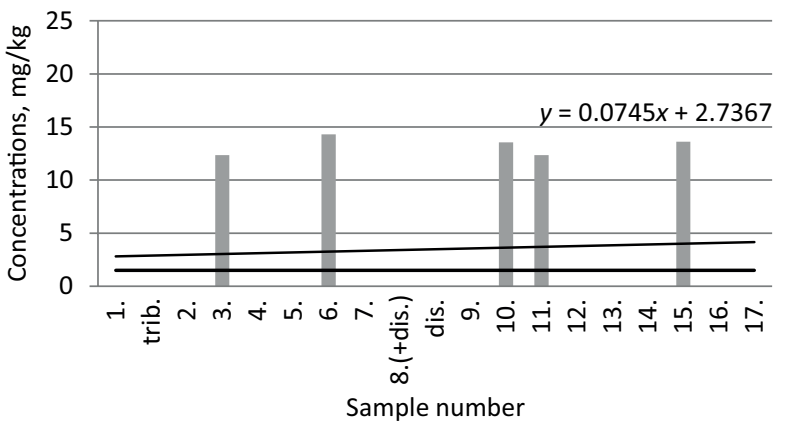

Fig 11. Cd concentrations on the right bank, downstream trend $(y)$, the concentration of the I sludge category (bold line) the Nemunas River bottom sediments decreases downstream while on the left bank increases (Figs 7 and 8). Also concentrations of heavy metals on the left bank are much higher than on the right bank. This obviously shows higher pollution by heavy metals on the left bank of Nemunas river where are much more dischargers. Those dischargers bring more pollutants from Alytus city and its contamination sources.

All concentrations of heavy metals $(\mathrm{Cr}, \mathrm{Cu}, \mathrm{Cd})$ are noticeably higher on the left bank of the Nemunas River (Figs 7-12). This is due to the fact that industry is concentrated in this part of Alytus city. Bottom sediments near some of discharges were highly contaminated by heavy metals, especially on the left river bank. Most of the concentrations of HM increased downstream.

The Total pollution index $\mathrm{Zd}$ showed that the left bank of the Nemunas River bottom sediments pollution by $\mathrm{HM}$ is greater than the right bank. $\mathrm{Zd}$ of the right bank is 68.3 while $\mathrm{Zd}$ of the left bank is 78.6. These $\mathrm{Zd}$ values are attributed to hazardous contamination category $\left(32<Z_{d}<128\right)$ according to Lithuanian Hygiene Standard 60: 2004. It also shows the higher contamination by HM on the left bank of Nemunas River.

\section{Conclusions}

1. The analysis of heavy metals of the Nemunas River bottom sediments showed increased concentrations of 5 elements (Cd, Ni, Cr, Cu, Zn) in 2012. These heavy metals are considered to be the most dangerous.

2. The highest concentrations that exceed the permissible environmental standards were set to $\mathrm{Cd}$ and $\mathrm{Ni}$. The major exceedances are specific to $\mathrm{Cd}$ from 8.8 to 9.8 times above the permissible limits respectively on the right and left banks of the Nemunas River.

3. Sediments were assigned to the II sludge category according to LAND 20-2005 in terms of the highest concentrations of $\mathrm{Cd}$ and $\mathrm{Ni}$ in bottom sediments on both banks of the Nemunas River.

4. Heavy metals concentrations in bottom sediments dozens of times exceed the cleanest river (Skroblus) values

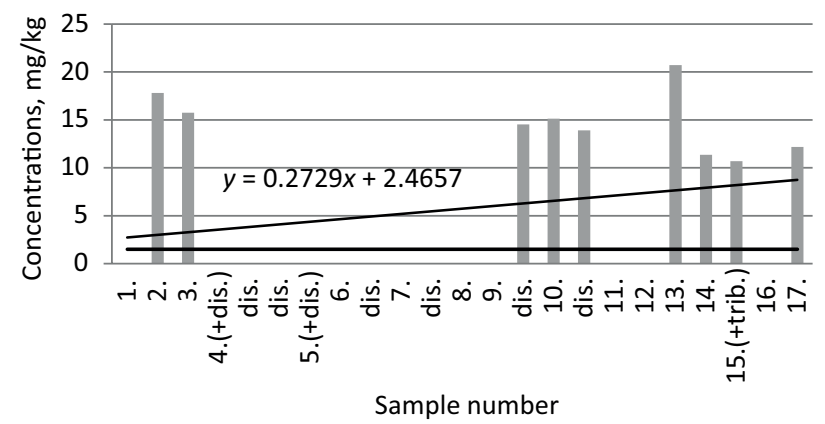

Fig 12. Cd concentrations on the left bank, downstream trend $(y)$, the concentration of the I sludge category (bold line) 
with the exception of $\mathrm{Pb}$ which was below the detection limit. Most of the heavy metals concentrations do not exceed the most contaminated river (Kulpè) values.

5. $\mathrm{Zd}$ of the right bank is 68.3 while $\mathrm{Zd}$ of the left bank is 78.6. According to $\mathrm{Zd}$ index $-13.1 \%$ higher contamination by heavy metals is observed on the left bank of the Nemunas River. Such distribution of contamination is due to the anthropogenic load and industrial enterprises located on the left part of the Nemunas River bank.

6. Trend equations showed the rising concentrations of heavy metals ( $\mathrm{Cr}$ (except right bank), $\mathrm{Cu}, \mathrm{Cd}$ ) going downstream the urban area. This shows the anthropogenic impact of the Alytus city on the Nemunas River ecosystem.

\section{References}

Bartoli, G.; Papa, S.; Sagnella, E.; Fioretto, A. 2011. Heavy metal content in sediments along the Calore river: relationships with physical-chemical characteristics, Journal of Environmental Management 95: 9-14.

http://dx.doi.org/10.1016/j.jenvman.2011.02.013

Chalmers, A. T.; Van Metre, P. C.; Callender, E. 2006. The chemical response of particle-associated contaminants in aquatic sediments to urbanization in New England, U.S.A., Journal of Contaminant Hydrology 91: 4-25. http://dx.doi.org/10.1016/j.jconhyd.2006.08.007

Davutluoglu, I. O.; Seckin, G.; Ersu, B. C.; Yilmaz, T.; Sari, B. 2011. Heavy metal content and distribution in surface sediments of the Seyhan River Turkey, Journal of Environmental Management 92: 2250-2259. http://dx.doi.org/10.1016/j.jenvman.2011.04.013

Farkas, A.; Erratico, C.; Vigano, L. 2007. Assessment of the environmental significance of heavy metal pollution in surficial sediments of the River Po, Chemosphere 68: 761-768. http://dx.doi.org/10.1016/j.chemosphere.2006.12.099

Fu, J.; Zhao, C.; Luo, Y.; Liu, C.; Kyzas, Z. G.; Luo, Y.; Zhao, D.; An, S.; Zhu, H. 2014. Heavy metals in surface sediments of the Jialu River, China: their relations to environmental factors, Journal of Hazardous Materials 270: 102-109. http:// dx.doi.org/10.1016/j.jhazmat.2014.01.044

Gregorauskienè, V. 2006. Mapping of geochemical contamination in urban areas of Lithuania, Journal of Environmental Engineering and Landscape Management 14(1): 52-57.

Guoren, X.; Mingwei, L.; Guibai, L. 2013. Stabilization of heavy metals in lightweight aggregate made from sewage sludge and river sediment, Journal of Hazardous Materials 260: 7481. http://dx.doi.org/10.1016/j.jhazmat.2013.04.006

Honglei, L.; Liqing, L.; Chengqing, Y.; Baoqing, S. 2007. Fraction distribution and risk assessment of heavy metals in sediments of Moshui Lake, Journal of Environmental Sciences 20: 390-397. ISSN 1001-0742.

Jankauskaitė, M.; Taraškevičius, R.; Zinkute, R.; Veteikis, D. 2008. Relationship between landscape self-regulation potential and topsoil additive contamination by trace elements in Vilnius city, Journal of Environmental Engineering and Landscape Management 16(1): 5-14.

http://dx.doi.org/10.3846/1648-6897.2008.16.5-14

Kadūnas, V.; Radzevičius, A. 2003. Comparative characteristics of change of trace element background values and associa- tions in Lithuanian surface sediments, Litosfera 7: 80-87. ISSN 1392-334X

LAND 20-2005. Requirements for the use of sewage sludge for fertilization and recultivation. Lithuanian Environmental Normative Document. Ministry of Environment of Lithuania.

Li, F.; Zhang, H.; Meng, X.; Chen, L.; Yin, D. 2012. Contamination by persistent toxic substances in surface sediment of urban rivers in Chaohu City, China, Journal of Environmental Sciences 24: 1934-1941. http://dx.doi.org/10.1016/S1001-0742(11)61033-4

Lithuanian Environmental Protection Agency. 2003. Accumulation of heavy metals in fish and sediments. Final project report of Lithuanian Environmental Protection Agency.

Lithuanian Hygiene Standard 60: 2004. Maximum allowable concentrations of hazardous substances in soil. Ministry of Health of the Republic of Lithuania.

Lourino-Cabana, B.; Lesven, L.; Charriau, A.; Billon, G.; Ouddane, B.; Boughriet, A. 2011. Potential risks of metal toxicity in contaminated sediments of Deule river in Northern France, Journal of Hazardous Materials 186: 2129-2137. http://dx.doi.org/10.1016/j.jhazmat.2010.12.124

Peng, J.; Song, Y.; Yuan, P.; Cui, X.; Qiu, G. 2008. The remediation of heavy metals contaminated sediment, Journal of Hazardous Materials 161: 633-640. http://dx.doi.org/10.1016/j.jhazmat.2008.04.061

Reza, R.; Singh, G. 2010. Heavy metal contamination and its indexing approach for river water, International Journal of Environmental Science and Technology 7(4): 785-792. ISSN 1735-1472. http://dx.doi.org/10.1007/BF03326187

Sen, B.; Varol, M. 2011. Assessment of nutrient and heavy metal contamination in surface water and sediments of the upper Tigris River, Turkey, Catena 92: 1-10. http://dx.doi.org/10.1016/j.catena.2011.11.011

Shefsky, S. 1997. Comparing field portable x-ray fluorescence (XRF) to laboratory analysis of heavy metals in soils, International Symposium of Field Screening Methods for Hazardous Wastes and Toxic Chemicals, 29-31 January 1997, Las Vegas, Nevada, USA.

Shu-Hai, G.; Xiao-Li, W.; Yu, L.; Jie-Jiang, C.; Jun-Cheng, Y. 2006. Investigation on $\mathrm{Fe}, \mathrm{Mn}, \mathrm{Zn}, \mathrm{Cu}, \mathrm{Pb}$, and $\mathrm{Cd}$ fractions in the natural surface coating samples and surficial sediments in the Songhua River, China, Journal of Environmental Sciences 18: 1193-1198. ISSN 1001-0742. http://dx.doi.org/10.1016/S1001-0742(06)60061-2

Suthar, S.; Nema, K. A.; Chabukdhara, M.; Gupta, K. S. 2009. Assessment of metals in water and sediments of Hindon River, India: impact of industrial and urban discharges, Journal of Hazardous Materials 171: 1088-1095. http://dx.doi.org/10.1016/j.jhazmat.2009.06.109

Taraškevičius, R.; Zinkutè, R. 2011. Urban geochemical anomalies of Lithuania and their spread, Baltica 24: 163-168. ISSN 0067-3064.

US EPA. 2006. XRF technologies for measuring trace elements in soil and sediment. US EPA Innovative Technology Verification Report, 4-8.

Vasarevičius, S.; Mineikaitė, A.; Vaitiekūnas, P. 2010. Investigation into heavy metals in storm wastewater from Vilnius Zirmunai district and pollutants spread model in Neris river, Journal of Environmental Engineering and Landscape Management 18: 242-249. ISSN 1648-6897. http://dx.doi.org/10.3846/jeelm.2010.28 
Wrobel, P.; Czyzycki, M. 2013. Direct deconvolution approach for depth profiling of element concentrations in multi-layered materials by confocal micro-beam X-ray fluorescence spectrometry, Talanta 113: 62-67.

http://dx.doi.org/10.1016/j.talanta.2013.03.087
Yujun, Y.; Zhifeng, Y.; Shanghong, Z. 2011. Ecological risk assessment of heavy metals in sediment and human health risk assessment of heavy metals in fishes in the middle and lower reaches of the Yangtze River basin, Environmental Pollution 159: 2575-2585.

http://dx.doi.org/10.1016/j.envpol.2011.06.011

Vaidotas VALSKYS. PhD in Ecology and Environmental Studies at the Ecology and Environmental Research Centre, Faculty of Natural Sciences, Vilnius University. Publications: author/co-author of 3 scientific papers, 1 scientific presentation in international conference and 2 scientific presentations in Lithuanian scientific conferences. Research interests: hydrology, water quality, limnology, environmental chemistry.

Roberta VALSKIENĖ. M.S. in Environmental Studies and Environment Management, at the Ecology and Environmental Research Centre, Faculty of Natural Sciences, Vilnius University. Now works at the laboratory of Genotoxicology, Institute of Ecology, Nature Research Center as a biologist. Publications: author of 1 scientific paper. Research interests: ecotoxicology, effects on the biota, water quality.

Gytautas IGNATAVIČIUS. Dr, Associate Professor of Environmental Engineering at the Ecology and Environmental Research Centre, Faculty of Natural Sciences, Vilnius University. He gained his Environmental Engineering PhD in 2002 at Vilnius Gediminas Technical University. Publications: author/co-author of over 50 scientific papers and over 30 scientific presentations in Lithuanian and international scientific conferences. Research interests: environmental chemistry, filtration process, soil chemistry. 